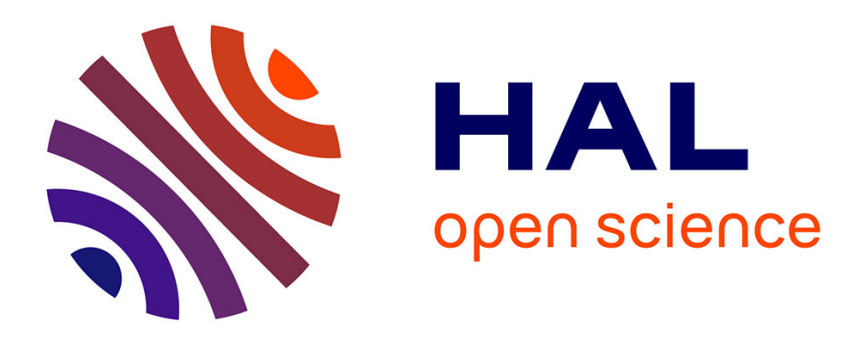

\title{
The Formation of Aerosols During the Co-combustion of Coal and Biomass
}

\author{
Ange Nzihou, B. R. Stanmore
}

\section{To cite this version:}

Ange Nzihou, B. R. Stanmore. The Formation of Aerosols During the Co-combustion of Coal and Biomass. Waste and Biomass Valorization, 2015, 6 (6), pp.947-957. 10.1007/s12649-015-9390-3 . hal-01632391

\section{HAL Id: hal-01632391 https://hal.science/hal-01632391}

Submitted on 16 Jan 2019

HAL is a multi-disciplinary open access archive for the deposit and dissemination of scientific research documents, whether they are published or not. The documents may come from teaching and research institutions in France or abroad, or from public or private research centers.
L'archive ouverte pluridisciplinaire HAL, est destinée au dépôt et à la diffusion de documents scientifiques de niveau recherche, publiés ou non, émanant des établissements d'enseignement et de recherche français ou étrangers, des laboratoires publics ou privés. 


\title{
The Formation of Aerosols During the Co-combustion of Coal and Biomass
}

\author{
Ange Nzihou' ${ }^{1}$ B. R. Stanmore ${ }^{2}$
}

\begin{abstract}
The global drive to lessen the emission of greenhouse gases in the power industry has seen an increase in the co-combustion of coal with various types of biomass. The practice "represent possibly the best (cheapest and lowest risk) renewable energy option for many power producers". Most reviews of the practice cite environmental benefits coupled with satisfactory technological performance. One environmental aspect which has been virtually ignored is the formation and release of ultrafine aerosol particles, which have a damaging effect on the respiratory system. The emission of respirable aerosols during the combustion of both coal and biomass has received considerable attention, but there is little information available for the combustion of their mixture. The available evidence, reviewed here, indicates that the extent of their formation is increased by co-combustion, due to the high ash and sulphur content of coals, and the high alkali metal content of biomass.
\end{abstract}

Keywords Aerosols - Biomass - Coal · Alkali metals · Co-combustion

B. R. Stanmore was formerly at the University of Queensland, Brisbane, QLD, 4072, Australia.

\footnotetext{
$\triangle$ Ange Nzihou

ange.nzihou@mines-albi.fr

1 Mines Albi CNRS, Centre RAPSODEE, Campus Jarlard, Université de Toulouse, 81013 Albi Cedex 09, France

2 University of Queensland, Brisbane, QLD 4072, Australia
}

\section{Introduction}

The substitution of biomass for coal is being promoted as a suitable response to the demand to lower mankind's release of carbon into the atmosphere. Many reports on the cocombustion of various forms of biomass comment favourably on the overall emission levels e.g. Baxter, Grammelis, Hartmann, Luts, but most do not take account of the ultrafine particles [1-4]. For example, in their assessment of the particle size distribution of ash, Grammelis report the particle size distribution (psd) of the ash to a minimum 'bin' size of $<53 \mu \mathrm{m}$ [2]. Hartmann et al. [3] address greenhouse and acid gas emissions, but ignore particulates. In his review of the topic, Baxter [1] focusses on the properties of fly ash with regard to fouling, corrosion and use as a cement extender, but ignores its environmental effects.

The co-combustion of biomass with coal must take account of the different physical properties of the two fuels. The low density and lower specific energy of biomass restricts the extent of its application, as its overall energy density is approximately one tenth of that of coal. Consequently, co-firing biomass at a $10 \%$ heat input rate results in volumetric coal and biomass flow rates of comparable magnitude [1]. Even though it may contribute only a fraction of the energy and mass input to a coal-fired boiler, it has the potential to significantly alter the physicochemical environment in the flame.

\section{Airborne Aerosols}

A sample of urban air may contain $10-100 \times 10^{3}$ particles per $\mathrm{cm}^{3}$, which on a mass basis may be $20-100 \mu \mathrm{g} \mathrm{m}^{-3}$. The number concentration is dominated by fine particles, 
and the mass loading by large particles. It is the very small particles which are of most interest for air quality, because of their effects on human health. The term "nanoparticles" is applied to those $<50 \mathrm{~nm}$ in diameter [5]. The "ultrafine" category is generally defined as being smaller than $0.1 \mu \mathrm{m}$ $(100 \mathrm{~nm})$, or $\mathrm{PM}_{0.1}$, while the legislation is specified in terms of $\mathrm{PM}_{10}$ and $\mathrm{PM}_{2.5}$. It is the latter size category which is known to damage respiratory systems.

Airborne aerosols are comprised of material from a number of different sources, which is reflected in their composition. The primary particles may be originally siliceous or carbonaceous, or salt from an evaporated droplet of seawater, or be of biological origin. Subsequent secondary growth by adsorbed water, salts and organics produces a complex mixture of these components. Because of their small size, they can remain suspended in the atmosphere for long periods.

Urban aerosols begin life in the nucleation mode (1-2 nm), formed predominantly in combustion processes. Both gasoline and diesel motors are responsible for a large part of the nucleation mode particles in the built environment, with coal combustion also contributing [6]. The particles then grow by coagulation when moisture, organic molecules and gases are adsorbed onto their surface to form ammonium, sulphate and nitrate radicals (accumulation mode). The large sizes ("coarse fraction" $>1 \mu \mathrm{m}$ ) settle quickly and are not present in high concentrations. Polyaromatic hydrocarbons (PAH) and their oxy and nitro derivatives are present on the surface.

The growth of fine particles by 'accumulation' is well illustrated by a program to follow the changes in a parcel of air originating above the Pacific Ocean off the coast of California [7]. The particles were sampled at four sites, the first originally at sea i.e. with a salt nucleus, and then as the air passed over urban Los Angeles. The particles grew in size by the accretion of predominantly nitrogenous (ammonium, nitrate) and organic species adsorbed from the urban pollution background, Fig. 1. The quantity and composition of the particles measured at Long Beach on the coast, shown in Fig. 1 can be contrasted with those inland at Riverside, where the parcel of air arrived approximately $8 \mathrm{~h}$ later.

Since the combustion of both coal and biomass represents potential sources of nuclei for the formation of aerosols, attention has been focussed on their performance. The literature is well stocked with reports on the quantity of aerosol release in both cases, while the respective formation mechanisms have been extensively investigated. However, the adoption of co-combustion for these two fuels generates a different flame environment which has not been adequately examined. This paper explores the likely effects of co-combustion on ultrafine or fume emissions.

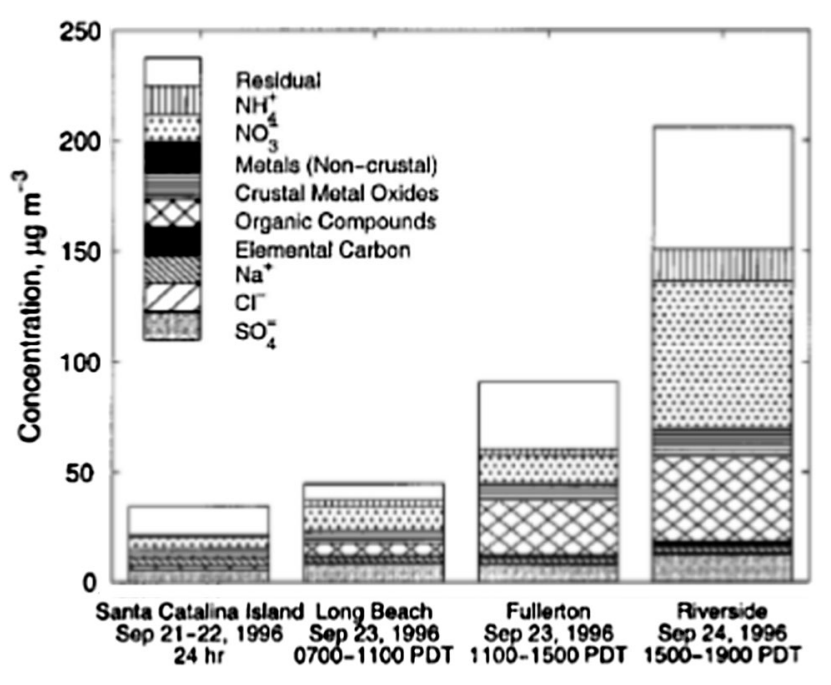

Fig. 1 Composition of total suspended particulates [7]

\section{Aerosol Formation During Coal Combustion}

The source of fine particles during coal combustion is the included minerals, such as pyrites and clays, and some organically-bound elements such as sulphur and metals. The minerals are oxidised and melt during combustion to form ash, sometimes losing water of hydration and decomposing e.g. carbonates. Commercial coals generally produce an ash yield of between 10 and $25 \%$ of the dry fuel mass. Organically associated trace elements exposed to very high temperatures and a highly reducing environment will be released from the coal matrix when the associated bonds break. The morphology of submicron particles from pulverised coal (pc) combustion, like those in the micron range, is overwhelmingly spherical [8].

Most of the mass of the mineral matter in coal is originally finely distributed in pulverized coal particles either as micron-size inclusions or organically bound to the coal. During combustion the mineral inclusions in coal fuse, adhere to the receding carbonaceous surface, and coalesce to form particles in the size range of 1-30 $\mu \mathrm{m}$ with typical mass mean diameters in the range of 5-10 $\mu \mathrm{m}$ [9]. The process of fume production described by Seames [10] is depicted in Fig. 2.

Coal combustion for power generation is generally carried out in pulverised fuel boilers at maximum temperatures around $1500-1600{ }^{\circ} \mathrm{C}$, although fluidised beds, which operate at $900{ }^{\circ} \mathrm{C}$ are becoming more popular. An early report on ash behaviour during pc combustion was presented by Pueschel [11], who tracked particles in the downwind plume of a coal-fired power plant for $32 \mathrm{~km}$. Micrographic analysis of the fine particles $0.05<\mathrm{d}_{\mathrm{p}}<$ $1.0 \mu \mathrm{m}$ showed that at all locations silicon and aluminium were distributed evenly throughout their interior, while 
Fig. 2 Mechanism for fume production during coal combustion [10]

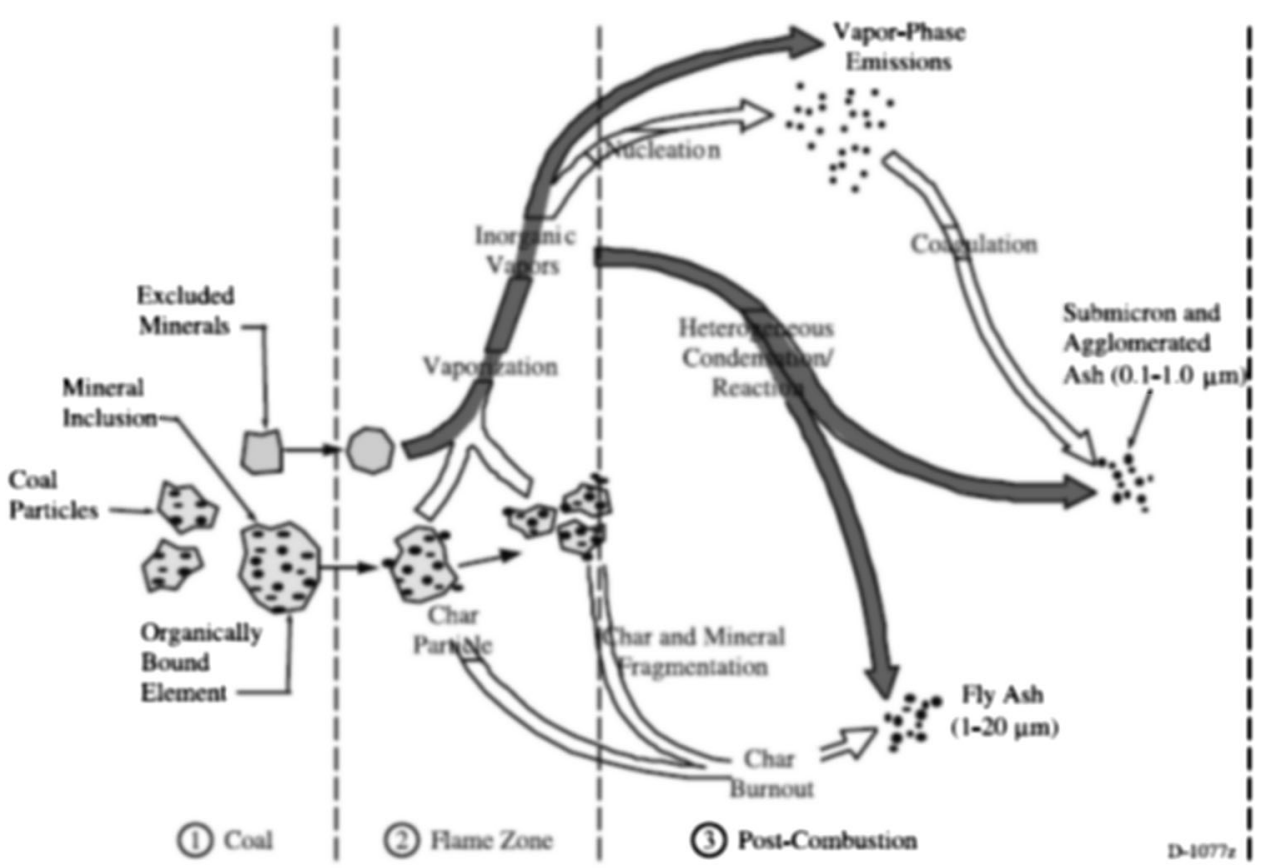

sulphur and chlorine were concentrated in an outer shell. This illustrated previous conclusions that sulphate and chloride species had condensed from the vapour phase onto larger ash particles while the fluegas/particles were still passing through the furnace flow system.

Volatile oxides or metals expelled at high temperatures to the gas phase can become supersaturated, and thus homogeneously nucleate to form a very large number of nano-particles (probably much smaller than $0.01 \mu \mathrm{m}$ ). For coal, aerosols in the $0.02-0.1 \mu \mathrm{m}$ size range form initially by nucleation of $\mathrm{Si}, \mathrm{Ca}$ and $\mathrm{Al}$ vapour species, with subsequent accumulation of other volatiles, such as sulphate and chloride, and to a lesser extent $\mathrm{As}, \mathrm{Sb}$ and $\mathrm{Zn}$. This results in a bimodal, or sometimes trimodal, psd in the product coal ash.

A recent review of the process by $\mathrm{Xu}$ et al. [12] notes that vaporisation is favoured by high particle temperatures and a reducing environment. With coals, especially lignite, metals are present as salts at surface carboxylic and phenolic groups. The same applies to biomass, see [13]. Metals contained in clays typically do not vaporise [14]. When metal oxides in the gas phase nucleate to form small particles, these can grow by accumulation or coagulation mechanisms. In the former, further condensation takes place, while the latter represents collisions in which the particles coalesce. Xu et al. [12] also identifies surface ash shedding, bubble bursting and the carryover of fine fuel particles as other nuclei sources for the accumulation of vapour species.

The presence of refractory oxides like silicon, calcium and magnesium in fume has been explained by Christensen et al. [15] as taking place in temperature ranging from 800 to $1000{ }^{\circ} \mathrm{C}$ in reducing atmosphere within the particle. The normal ash species $\mathrm{SiO}_{2}, \mathrm{MgO}$ and $\mathrm{CaO}$ can be reduced to the more volatile $\mathrm{SiO}, \mathrm{Mg}$ and $\mathrm{Ca}$. When these vapours leave the particle, they are re-oxidised to the standard oxides, some of which then homogeneously nucleate. The oxidation of $\mathrm{SiO}$ is slow, so that other oxides probably form first. More volatile species such as potassium, sulphate and chloride can later condense onto the surface of the nuclei as the gas cools. It was found in a pilot scale furnace [16] that increasing the combustion temperature for a bituminous coal led to a decrease in the amount of micron size particles, but an increase in the ultrafine submicron range. This is consistent with increased volatilisation followed by condensation, see Fig. 2.

The amount of submicron ash $(<0.54 \mu \mathrm{m})$ from a range of coals when burned at $1750 \mathrm{~K}$ in gas containing $0.2 \mathrm{~atm}$ of oxygen was found to lie between 0.54 and $9.6 \%$ of the ASTM ash [17]. This was equivalent to 7.2-65 mg of fume per $\mathrm{kg}$ of coal burned. Coals of lower rank produced more aerosol. A similar study by Buhre et al. [18] on five bituminous coals in a drop tube furnace found similar results, with fume accounting for between 0.12 and $1.6 \%$ of the total ash formed. The coals with higher sulphur content tended to produce more aerosols, as illustrated in Fig. 3. Although Coal 240 contained more sulphur than Coal 272, it formed less aerosol, probably because it contained considerably less of the complementary alkali metals.

Modelling of fly ash-forming processes has been widely undertaken. For the aerosol component, a routine developed by Jokiniemi et al. [19] develops mathematical 


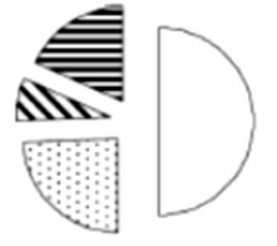

CRC 240

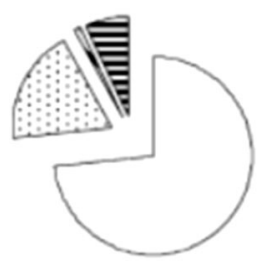

CRC 297

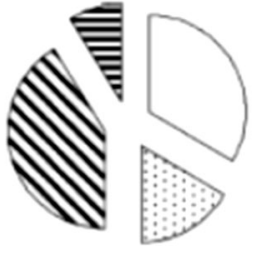

CRC 272

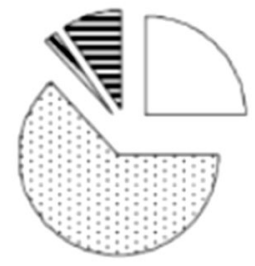

CRC 306

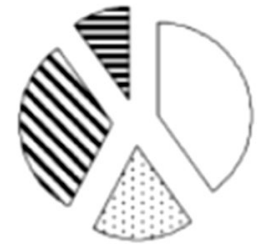

CRC 296
Fig. 3 Composition of fume formed during the combustion of five bituminous coals [18]

descriptions of nucleation, condensation, coagulation, chemical reactions and deposition. They found that the ash particle size distribution is formed early in the combustion sequence, and is virtually unchanged over the final section of the ducts leading to the ESP. The model indicates that it is important to know the volatilisation of sodium, potassium, chlorine and sulphur, and also the rate of formation of alkali sulphates in the gas phase. The initial ash size distribution determines the distribution of condensed alkalis between the sub- and super-micron particle modes, because much smaller saturation ratios are necessary for heterogeneous nucleation to take place than in the case of homogeneous nucleation. For homogeneous nucleation to occur, super-saturation of the vapour is necessary. However, if there is an existing nucleus, the required free energy is less and condensation readily takes place.

In summary, the literature identifies sulphur as the major ash component which drives the formation of aerosols. The alkali and alkaline earth elements provide the cationic balance for the sulphate products. Pyrites is the most common form of inorganic sulphur in coals, and is also the location of the bulk of arsenic, selenium and antimony. Silicates do not appear to contribute in a significant way, but phosphorus has been identified as active in some coals.

Fluidised bed combustion is operated at lower temperatures than $\mathrm{pc}$ furnaces, so that the extent of mineral devolatilisation tends to be lower. For example no significant vaporization was observed for $\mathrm{Ca}, \mathrm{Al}, \mathrm{Fe}, \mathrm{Mg}$, and $\mathrm{Si}$ in CFBC [12]. The morphology of the ash particles is not spherical, but irregular, because complete fusion has not taken place [8]. As a result the concentration of aerosols tends to be lower during this form of co-combustion.

\section{Aerosol Formation During Biomass Combustion}

Many investigations into aerosol formation during biomass combustion have been produced in Scandanavian countries, where the practice is widespread. Although biomass has a lower ash content than coal, typically $0.5-1 \%$ for wood and 4-8\% for agricultural by-products, it is rich in volatile elements like potassium and chlorine. For example, in a range of straws the potassium content was as high as $2 \%$ of the dry weight [15]. Their sulphur content was constant at $0.1 \%$, while the chlorine was approximately proportional to the potassium content at $40 \%$ of its weight.

The extent of release into the vapour phase of $\mathrm{K}, \mathrm{Cl}$ and $\mathrm{S}$ was measured for wood chips and corn stover (the leaf, husk and cob remaining after harvest) by Johansen et al. [20]. The effect of temperature for potassium is shown in Fig. 4; it rises from $40 \%$ at $900{ }^{\circ} \mathrm{C}$ to $80 \%$ at $1300{ }^{\circ} \mathrm{C}$. Chlorine is even more volatile, as is sulphur. They found that the scale of operations i.e. lab, bench and pilot scale modifies their behaviour, and secondary reactions influence the amount and speciation of chlorine.

When potassium is in excess in relation to chlorine in a biomass feed, it is largely retained in the residual i.e. bottom ash under grate combustion conditions [16]. With mixtures of wood chips and high $\mathrm{Cl}$ corn stover, the release of K per gram of fuel remained almost constant, regardless of the available amount of $\mathrm{Cl}$. This occurred even though the maximum temperature varied by about $200{ }^{\circ} \mathrm{C}$. Most of the $\mathrm{Cl}$ present was released as $\mathrm{HCl}$ rather than alkali chlorides.

Nussbaumer [21] notes that biomass combustion leads to relatively high emissions of particulates i.e. well above $50 \mathrm{mg} \mathrm{Nm}^{-3}$ at $11 \% \mathrm{O}_{2}$. The majority of these are smaller than $10 \mu \mathrm{m}\left(\mathrm{PM}_{10}\right)$, with a high share of submicron particles $\left(\mathrm{PM}_{1}\right)$. The main constituents of biomass aerosols are $\mathrm{K}, \mathrm{Cl}, \mathrm{S}, \mathrm{Ca}, \mathrm{Na}, \mathrm{Si}, \mathrm{P}, \mathrm{Fe}$ and $\mathrm{Al}$. For a number of biomass types viz wood, demolition wood and coffee wastes,

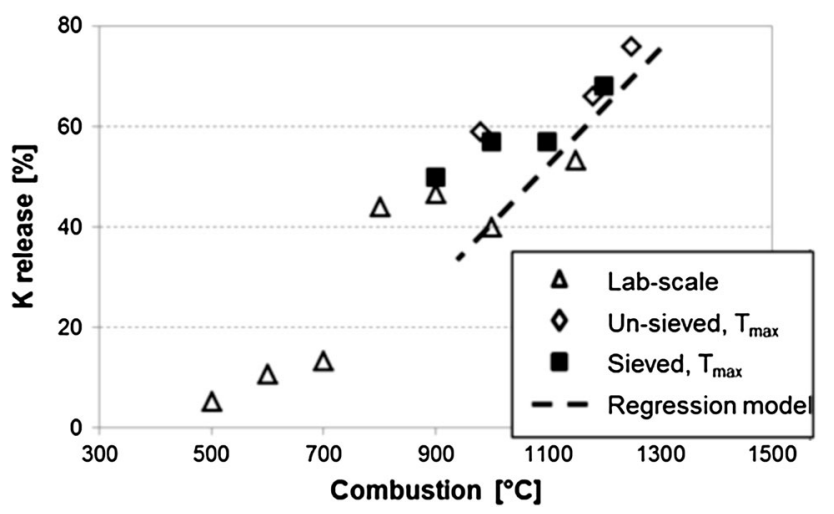

Fig. 4 Fractional release with temperature of potassium from corn stover [20] 
Becidan et al. [22] report that $\mathrm{K}, \mathrm{S}, \mathrm{Cl}$ and $\mathrm{Na}$ dominated the aerosol composition. It was shown by Gao and $\mathrm{Wu}$ [23] that the ultrafines are produced mostly from the volatiles, and not during char combustion.

It is now common to regard biomass ash as composed of 'reactive' and 'non-reactive' components [24]. The non-reactive constituents e.g. the silica-based mineral matter, is assumed to remain unchanged during FBC and is regarded as virtually inert. As noted below, this may not always be the case with pulverised fuel firing. The reactive fraction, typically alkali compounds, will be easily converted into new compounds during combustion, particularly by sulphur and chlorine. The formation of aerosols will be a function of these reactive components. Any reaction between alkali species and the silicate phase will predominantly take place in the condensed phase, as no significant increase in the retention of potassium in the ash has been observed with increasing residence time [21].

An illuminating study on aerosols in a grate-type MSW furnace is reported by Brunner et al. [25]. Using a high temperature impactor, they sampled aerosols $(0.09-1.26 \mu \mathrm{m})$ in the gas stream at four locations: the afterburner shaft $\left(978{ }^{\circ} \mathrm{C}\right.$ average), the downshaft $\left(674{ }^{\circ} \mathrm{C}\right)$, the convective superheater duct $\left(541^{\circ} \mathrm{C}\right)$ and the economiser duct $\left(363{ }^{\circ} \mathrm{C}\right)$. The quantities involved increased by a factor of SIX over the test path. At the high temperature point, the ultrafines were predominantly silicon and calcium, whereas once the gas had cooled to $670{ }^{\circ} \mathrm{C}, \mathrm{Na}, \mathrm{K}, \mathrm{S}$ and $\mathrm{Cl}$ also appear in roughly equal and significant amounts. For the last two positions, the compositions are dominated by $\mathrm{Na}, \mathrm{K}$ and $\mathrm{Cl}$, with traces of other semi-volatile metals.

This result appears to confirm the proposition that two mechanisms can generate silicon, aluminium and calciumrich nuclei from fuel ash. Firstly, thermal stresses can fracture excluded minerals to generate submicron fragments. Secondly, at a high temperature and in a reducing atmosphere, such as that in a char particle, oxides of $\mathrm{Si}, \mathrm{Al}$, $\mathrm{Mg}$ and $\mathrm{Ca}$ embedded in the particles may be reduced to easily volatile suboxides such as $\mathrm{SiO}$ or $\mathrm{Al}_{2} \mathrm{O}$, which can be released into the gas phase. These are subsequently reoxidised and being readily supersaturated, nucleate homogeneously.

A similar time-resolved study of wood and bark combustion $[26,27]$ undertook sampling of the particles in the flue gas at nine positions in a vertical furnace, ranging in temperature from 1450 to $400{ }^{\circ} \mathrm{C}$. Two size modes were present, a coarse mode located between 0.219 and $3.253 \mu \mathrm{m}$ with a mode diameter of $0.523 \mu \mathrm{m}$, and a fine mode located between 0.033 and $0.219 \mu \mathrm{m}$ with a mode diameter of $0.085 \mu \mathrm{m}$. Surprisingly, the mass contained in the fine mode was larger than that of the coarse mode.
Particles from incomplete combustion (soot and/or other hydrocarbon particles) dominated the fine mode composition early in the fuel-rich flame, but were rapidly oxidized in the hot oxygen-rich flow downstream. At the third sample point $\left(975{ }^{\circ} \mathrm{C}\right)$ there were approximately $18 \%$ of fines present as K, $12 \%$ as S, $11 \%$ as $\mathrm{Na}$ and $2 \%$ as $\mathrm{Zn}$. Thereafter the fine mode was dominated by the inorganic elements $\mathrm{K}, \mathrm{Na}, \mathrm{S}, \mathrm{Cl}, \mathrm{O}$ and $\mathrm{Zn}$. The coarse mode particles were generally similar, but contained significant amounts of $\mathrm{Ca}$ and $\mathrm{Mg}$, as well as lesser amounts of $\mathrm{Si}, \mathrm{Mn}$ and $\mathrm{Fe}$. A high alkali to silicon ratio $(\mathrm{K}+\mathrm{Na}) / \mathrm{Si}$ increased the amount of vaporised aerosol.

The submicron ash fraction generated from orujillo (a waste from olive production) in a laboratory drop tube furnace over a range of temperatures amounted to about $3 \%$ of the total ash [28, 29]. Many elements in the biomass were recovered in the $\mathrm{PM}_{1}$, with $\mathrm{As}, \mathrm{Pb}, \mathrm{Cr}, \mathrm{Cu}, \mathrm{Ni}, \mathrm{Zn}$, $\mathrm{Co}, \mathrm{Mn}$ and $\mathrm{Fe}$ represented (in decreasing amounts as listed). Elements prior to cobalt in this list were enriched over the feed ash, indicating some vaporisation and subsequent condensation. They conclude that the amount of fine particles generated is essentially fixed by the amount of volatilised alkali, and the ratio [sulphate]/[chloride] has a minor effect on the total mass emitted. $\mathrm{Pb}$ was found to condense in the temperature range $900-560{ }^{\circ} \mathrm{C}$, whereas $\mathrm{Cu}$ remained partly as vapour at $560{ }^{\circ} \mathrm{C}$.

Glarborg and Marshall [30], and Hidiyarti et al. [31] identified the importance of alkali sulphation to aerosol formation, and developed models for the gaseous sulfation of alkali hydroxide and alkali chloride which rely on detailed chemical kinetic models for the high-temperature gas-phase interaction between alkali metals, the $\mathrm{O} / \mathrm{H}$ radical pool, and chlorine/sulphur species. The role of sulphur oxidation as the limiting step in the formation of alkali sulphate was later confirmed [32], and the importance of the gas cooling rate on determining the amount of sulphate formed and, as a consequence on the properties of fine particles.

A simple plug flow model of aerosol formation in biomass boilers was developed by Jöller et al. [33, 34], and verified in various furnaces of different size and type. An aerosol population balance was utilised, together with a gas phase mass balance. The appropriate growth mechanisms such as coagulation, nucleation and condensation were combined with various mass transport mechanisms. The routine was applied to clean wood chips, waste wood and coal-wood co-combustion. For clean wood chips, the aerosols are predominantly $\mathrm{K}_{2} \mathrm{SO}_{4}$ and other alkali compounds $\left(\mathrm{Na}_{2} \mathrm{SO}_{4}, \mathrm{KCl}, \mathrm{NaCl}\right)$. Thermodynamic considerations show that alkali sulphates are less volatile than the chlorides, beginning to condense around $950{ }^{\circ} \mathrm{C}$. Alkali chlorides condense on these nuclei at a lower temperature, $\sim 600{ }^{\circ} \mathrm{C}$. The use of higher air rates in a fixed bed furnace 
burning wood and bark produced increased quantities of aerosols, which was explained by increased combustion temperatures [34].

When waste wood was combusted by Jöller et al. [33], the feed was contaminated with metals which strongly influenced the result. The zinc present formed $\mathrm{ZnO}$ at high temperatures and began to condense around $1000{ }^{\circ} \mathrm{C}$, thus providing sufficient nuclei for heterogeneous condensation of the alkali sulphates. Hence there were far more ultrafine particles present. With an abundance of sulphur in the fluegases, any $\mathrm{KCl}$ present, which had condensed earlier in such systems can be converted to $\mathrm{K}_{2} \mathrm{SO}_{4}$ [33]. The cocombustion result will be discussed below.

\section{Aerosol Formation During Co-combustion}

The few papers found on the subject of coal-biomass aerosols will be reviewed. A relevant study of the topic was carried out by burning orujillo at $1300{ }^{\circ} \mathrm{C}$ in a laboratory furnace to identify the aerosol products [27]. With orujillo alone, these were found to be $\mathrm{K}_{2} \mathrm{SO}_{4}$ and $\mathrm{KCl}$ in approximately equal amounts. In a second test the biomass was burned in a mixture of 2:1 mass ratio of $2.25 \%$ sulphur coal. Under these conditions the mixture produced more submicron particles, and of a smaller size, than when orujillo was burned alone. With high sulphur present, as with the coal, coke or $\mathrm{SO}_{2}$ addition, sulphate displaced chloride from the aerosol. A repeat run with orujillo-coal at $1450{ }^{\circ} \mathrm{C}$ also produced more material in the submicron range, as reproduced in Fig. 5.

The participation of sulphur in the process was confirmed by adding gaseous $\mathrm{SO}_{2}$ at $180 \mathrm{ppm}$ to the furnace burning only orujillo, where a similar, but even more pronounced effect, was found. When a $6.34 \%$ sulphur petcoke was burned with the orujillo, the ultrafine

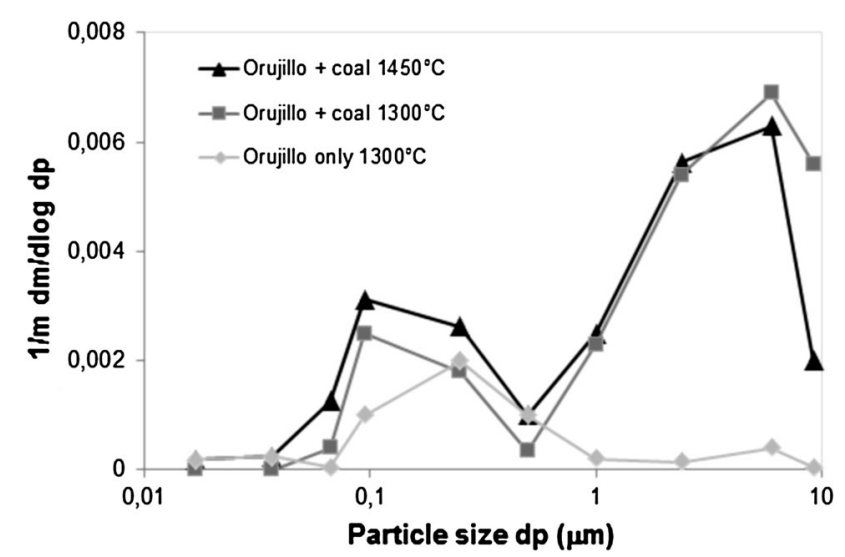

Fig. 5 Particle size distribution (mass basis) of ash formed during the co-combustion of coal and orujillo [28] component was increased but the micron range material was greatly reduced. This may have been because the coke contained only $2 \%$ ash, compared to $21 \%$ for the coal, which is consistent with preferred heterogeneous condensation in the model of Jokiniemi et al. [19] mentioned above.

The work of Seames [10] in an entrainment flow furnace showed that the co-combustion of sewage sludge (SS) increased the emission of aerosols. The furnace was operated at a burner temperature of $1500{ }^{\circ} \mathrm{C}$ with bituminous coal, SS and a 50:50 mixture of the two on a heat-release basis. The supermicron size material distributions were similar for each of the three feeds, whereas the major difference in the psd was in the submicron range. The mixed feed displayed an enhanced concentration band below $0.3 \mu \mathrm{m}$, as depicted in Fig. 6 .

In contrast, a laboratory study of sewage sludge burned with pulverised coal at $1200{ }^{\circ} \mathrm{C}$ in a laboratory furnace found that the amount of $\mathrm{PM}_{10}$ actually decreased when compared to straight coal [34]. When burned independently, sewage sludge produced over ten times more $<1 \mu \mathrm{m}$ material than did the low ash, $0.5 \% \mathrm{SO}_{3}$ content coal. However, even when burned in a 1:19 SS:coal mass ratio, the formation of $\mathrm{PM}_{10}$ was suppressed to near the coal value. The authors propose that fine $\mathrm{Si}-\mathrm{Al}$ minerals from the coal preferentially adsorb the $\mathrm{P}$ and $\mathrm{S}$ emitted from the sewage sludge, thus eliminating homogeneous nucleation/condensation.

Apparently the high phosphorus content of the SS played a significant role in the ash formation process. Phosphorus content in the sewage sludge is particularly high indeed in regards to the literature where the phosphorus content ranging from 1 to $6 \%$ are reported [36]. This is explained by the origin of the SS. The SS contained $15 \%$ ash (db), of which $27 \%$ was in the form of

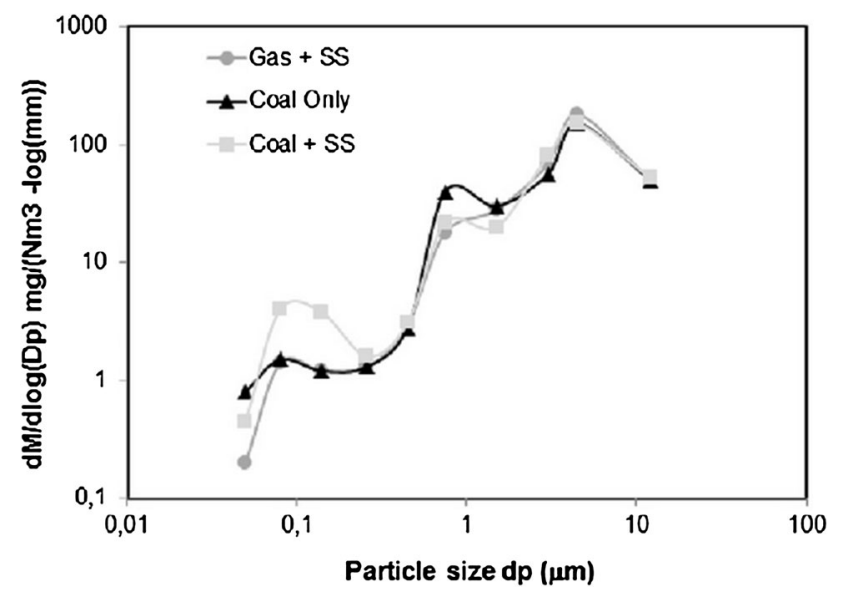

Fig. 6 PSD of particles formed in a pilot furnace when burning SS only (natural gas assisted), coal only and a coal-SS blend [35] 
phosphorus, and $12 \%$ as sulphur. The concentration of potassium in the SS and coal ash was $>1 \%$, and that of sodium about $1 \%$ each. In the 1:9 mass ratio SS:coal test, the combined mass of alkalis was approximately equal to the combined mass of the $\mathrm{P}$ and $\mathrm{S}$ concentrations. Phosphorus was the dominant element in the $\mathrm{PM}_{1}$ product, but was barely represented in the $1<\mathrm{d}_{\mathrm{p}}<10 \mu \mathrm{m}$ and $>10 \mu \mathrm{m}$ samples. It appears that in this case alkali phosphates have preferentially condensed onto existing coal ash particles. Phosphorus is a known fluxing agent [37], and will lower the melting point of ash particles into which it becomes incorporated. Wang et al. [38] propose that larger melted $\mathrm{Ca}-\mathrm{Fe}-\mathrm{Al}-\mathrm{Si}$ or $\mathrm{Ca}-\mathrm{Fe}-\mathrm{P}-\mathrm{Al}-\mathrm{Si}$ particles possess a large viscous surface which captures volatile elements like $\mathrm{P}$ and $\mathrm{S}$, and toxic elements such as $\mathrm{Zn}$.

It was found by Seames [10] that the addition of SS to coal can change the speciation of the arsenic and selenium compounds emitted. The As and Se were scavenged by calcium to form calcium arsenates and selenates, which are likely to be more benign than the oxides. Thus there is a trade-off, environmentally, for SS co-combustion with coal. More fine particles are generated, but these particles may decrease the emission of these semi-volatile trace elements as vapour and/or ultrafine particulate matter.

The tests by Jöller et al. [34] in a 404 MWth pulverised fuel furnace indicate that particle formation over the submicron range during co-combustion of coal and sawdust is greater than for coal alone. The fines collected from the last four impactor stages ranged in median size from 0.09 to $0.70 \mu \mathrm{m}$. They contained between 30 and $50 \% \mathrm{Si}$, with calcium and sulphur also well-represented. The concentrations of the latter two elements were higher in the fines, while $\mathrm{Si}$ showed the opposite trend. The mechanics are strongly influenced by the psd and the chemical composition of the submicron particles resulting from the defragmentation of coal ash (consisting mainly of $\mathrm{Al}, \mathrm{Ca}, \mathrm{Fe}, \mathrm{K}$ and $\mathrm{Si}$ ). The bulk of the nuclei appear to come from this source.

In the accompanying modelling exercise (see above), the Jöller routine gives a satisfactory simulation of the amount and psd of the ash formed, including the aerosols. This predicts that the formation processes are essentially complete by the time the gas reaches the stack. The release of $\mathrm{Ca}$ to the gas phase at high temperatures and the subsequent nucleation of $\mathrm{CaO}$ particles during cooling of the flue gas could be reproduced. Further growth may well take place after the ultrafines enter the atmosphere, as indicated by the experience of urban aerosol accumulation in Los Angles described in the introduction.

In considering the likely effects of co-firing, a complex physico-chemical system involving gas, liquid and solid phases results, with a large temperature range traversed under both localised reducing and oxidising conditions.
The type of combustion system will influence the reaction sequence and conditions. Also, it is apparent that the results are strongly influenced by the composition of the mineral components present in the ash. For example, the presence of high amounts of phosphorus in a sewage sludge modified the usual behaviour of the system.

When biomass is co-combusted with coal, the coal provides a high ash burden which can provide surface on which vapours can later condense. Excluded mineral matter can fragment to generate fine particles, and reducing conditions inside char particles at the high temperatures found early in the flame will add to the stock of nuclei. The latter will be based on $\mathrm{Ca}, \mathrm{Mg}, \mathrm{Si}$ and $\mathrm{Al}$ species. The smaller the particle, the larger the available surface area to mass, so that fines provide the bulk of the available area for heterogeneous deposition. The volatile species present, such as alkalis, sulphur and chlorine, and semi-volatile transition metals will remain in the gas phase at this stage.

As the gas stream cools, the semi-volatiles will begin to condense sequentially, followed by the more volatile species. This means that biomass, which is rich in aerosolforming species, will provide material for heterogeneous condensation onto the particle surface. When biomass is combusted alone, the overwhelming number of aerosol particles result from homogeneously-formed nuclei. During co-combustion, the minerals in the coal provide nuclei earlier in the combustion process, and are generally present in the order of $15-20 \%$ of the coal mass.

The presence of the biomass with the coal means that extra volatiles are present to undergo homogeneous condensation. Hence there is the potential to form more particles i.e. $\mathrm{PM}_{2.5}$ than when burning coal alone, and in some cases, than when burning the biomass alone. The latter is true in the case of Jiménez et al., Seames et al. and Wiinikka and Gebart [29, 30, 35]. The process will be exacerbated by the relatively high sulphur content of most coals. This is illustrated by the extent of $\mathrm{K}$ volatilisation being controlled by the $\mathrm{K} / \mathrm{Cl}$ ratio as noted by Johansen [20], and the identification of a $(\mathrm{K}+\mathrm{S}) / \mathrm{Si}$ ratio by Wiinikka et al. [27].

When biomass added to coal in BFB, the concentration of ultrafines increased out of proportion to the extremely low ash content of the added biomass [39]. They conclude that "the most important factor that could lead to the formation of very fine particles could be related with the presence of aerosol forming elements such as $\mathrm{K}, \mathrm{Na}$ and $\mathrm{Cl}$ in biofuels, which even resulted in higher PM emissions when the ash content of fuels decreased, as was the case of straw and olive bagasse".

Co-combustion of coal with biomass seemed to have the effect of moving the fly-ash in $\mathrm{PM}_{2.1}$ to a larger size range, but increasing the number counts of the ultra-fine particles 
[40]. The count of the ultra-fine particles at baseline (coal combustion) was about $7 \times 10^{5}$ particles per $\mathrm{cm}^{3}$. The counts were increased to $3 \times 10^{7}$ and $8 \times 10^{7}$ particles per $\mathrm{cm}^{3}$ for rice husk and bamboo respectively at $20 \%$ biomass addition. For pure rice husk and bamboo combustion, the ultra-fine particle counts were further increased to $3 \times 10^{8}$ and $5 \times 10^{8}$ particles per $\mathrm{cm}^{3}$. The increase for biomass co-combustion is not linear, but increases sharply with only a modest addition.

A recent publication illustrates the complexity of the reaction environment. When a coal fly ash was blown into an entrainment-fired $800 \mathrm{MWth}$ furnace burning wood pellets at coal ash-to-wood ash mass ratios of 2-4 [41], the quantity of submicron particles was greatly reduced. A spike in the psd plot around $0.2 \mu \mathrm{m}$ was almost eliminated. The authors suggest that the potassium emerged as amorphous potassium silicate and aluminosilicate phases. This is consistent with the mechanisms outlined above, where ash formed from the coal particles appears to be responsible for the greater portion of the nuclei formed. When the coal ash is in far lower concentration, and is of alreadyfused morphology at low supermicron particle size, it will presumably not fragment and act to form the basis for $\mathrm{K}, \mathrm{Cl}$ and $\mathrm{S}$ condensation.

It can be concluded that in general co-combustion operations based on coal as the primary fuel will produce an increase in sub-micron particles. The sulphates and $\mathrm{HCl}$ will interact to determine the final composition of the $\mathrm{PM}_{2.5}$. Other semi-volatile elements such as $\mathrm{Zn}, \mathrm{As}, \mathrm{Sb}$ and $\mathrm{Se}$ will also be incorporated into the ultrafines by vaporisation/condensation.

\section{The Effect of Gas Cleaning on Aerosol Removal}

Most of the data presented above has been collected from pilot-scale equipment, whereas any potential health effects from particulate matter will be the result of emissions from a commercial boiler installation. Since the furnace gases from a large plant will have been subjected to a gas cleaning operation, its effect on the concentration of aerosol particles needs to be considered. Either an electrostatic precipitator (ESP) or fabric filter (FF) would be employed. A search of the literature for ESP efficiencies shows that in all cases the least efficient collection is when the particle size is in the $0.1-1 \mu \mathrm{m}$ range [42-46], which is the very range identified here. For fabric filters, the result is similar, as the 0.1-1 range falls between two effects which determine FF performance i.e. diffusion and impaction/ interception [47]. These particles are too large for collection by diffusion and too small for collection by impaction or interception. For a range of filter types, there is a maximum penetration of the filter at sizes around $0.5 \mu \mathrm{m}$.
As a result of the information presented here, one can conclude that the operation of the gas cleaning systems of large co-combustion boilers will probably function least effectively with the offending particles. Although gas cleaning will reduce the particulate emissions by over $99 \%$, the ultrafines in them will actually become more concentrated.

\section{The Health Effects of Airborne Ultrafine Particles}

There is conclusive evidence that $\mathrm{PM}_{2.5}$ is associated with a range of health outcomes, including respiratory and cardiovascular diseases e.g. Kan et al. [48]. Their study examined the situation in Shanghai, an extremely polluted city, and found a close association between $\mathrm{PM}_{2.5}$ concentration and daily mortality rates. In contrast, they do not report a significant effect of $\mathrm{PM}_{10-2.5}$ on these rates. Even biologically-inert particles in micron sizes such as titanium dioxide and quartz have been shown to be active in submicron sizes [49]. It is therefore important to focus on the ultrafines in assessing any risk.

A review of the situation by Valavenidis et al. [50] found that the smaller the size of the PM, the higher the toxicity through mechanisms of oxidative stress and inflammation. Extractable organic compounds e.g. on diesel exhaust particulates, contribute to various mechanisms. The water-soluble fraction (mainly transition metals with redox potential) plays an important role in the initiation of oxidative DNA damage and membrane lipid peroxidation [51]. Any associations between chemical composition and particle toxicity tend to be stronger for the fine and ultrafine size fractions. Children are especially susceptible to induced respiratory problems [52].

When considering particles generated from biomass, it should be noted that some cautions have already been raised. The burning of biomass in a domestic appliance, even under excellent combustion conditions, gives reason to suspect that the $\mathrm{PM}_{1}$ may be harmful [53]. This is because they consist mostly of ultrafine aerosols in which inorganics such as zinc are represented. Poor combustion conditions result in fewer, larger particles, but these are still respirable and likely to have adsorbed PAH on the surface.

Fernandez et al. [54] found that pulmonary stress was created in mice exposed to coal/sewage sludge ash of nominal $3.5 \mu \mathrm{m}$ size, but not to coal ash alone. This was attributed to the action of transition metals, particularly zinc, which was significantly more concentrated in the SS/coal ash than in the coal ash particles themselves. The natural $\mathrm{pH}$ of the two sets of particles was similar. The effect is illustrated in Fig. 7, where mice were subjected to aerosol ingestion. Coal aerosols produced only a slight 


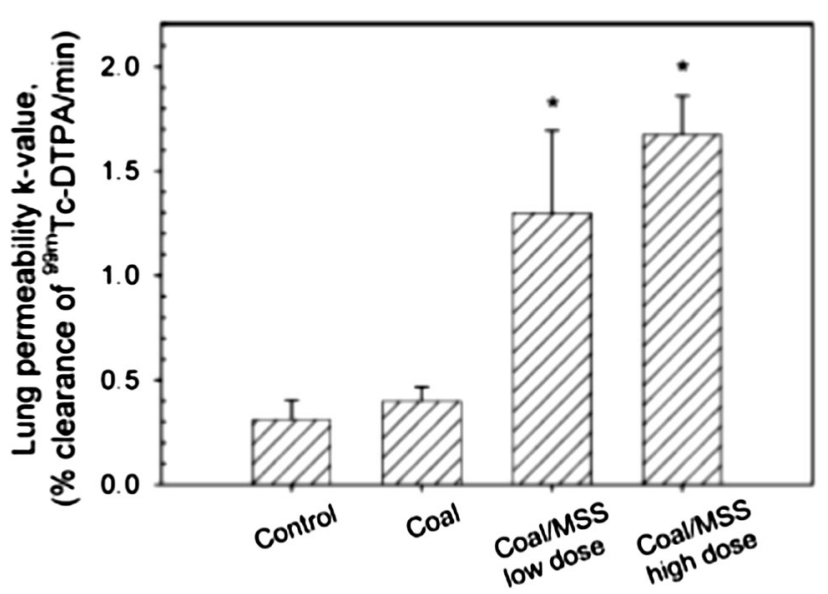

Fig. 7 Deleterious effect (in the form of increased permeability) on mouse lung tissue after the inhalation of aerosols. The control condition is room air [47]

effect on lung performance, whereas the material from cocombustion produced aggravated deterioration. Further work confirmed that it was the zinc from the SS, in conjunction with sulphur from the coal, which was responsible for the observed damage [55].

Since aerosols from co-combustion are likely to be readily soluble due to high concentrations of alkali metals, sulphates and chlorides, their potential for lung damage must be significant. In addition, the adsorption onto their surface of trace metals with redox activity has been noted, which indicates that this will contribute to detrimental health effects.

The regulation of particulate emissions is practised worldwide in order to lessen the impact of these effects. The EU emission limits for PM from large combustion plants burning solid fuel as recommended by the European parliament are $50 \mathrm{mg} \mathrm{Nm}^{-3}$ for plants $<100 \mathrm{MW}_{\mathrm{e}}$ and $30 \mathrm{mg} \mathrm{Nm}^{-3}$ for those $>100 \mathrm{MW}_{\mathrm{e}}$ [56]. The latter value is currently applicable in the USA also. Since the particles are specified as $\mathrm{PM}_{10}$, the miniscule mass contributed by the fine particles discussed above means they are virtually unregulated.

\section{Conclusion}

It appears that the co-combustion of biomass with coal, although beneficial in most aspects, will generally involve the release of an increased amount of aerosols into the atmosphere when compared with coal-only combustion, and in some cases with biomass-only combustion. This brings an increased health risks as a result of two hazards. Firstly, these fine particles themselves are known to produce adverse pulmonary effects, whatever their composition. They can also act as nuclei for subsequent agglomeration in an urban environment. Secondly they represent a vehicle for the transport over a wide area of respirable particles containing harmful transition metals such as zinc.

\section{References}

1. Baxter, L.: Biomass-coal co-combustion: opportunity for affordable renewable energy. Fuel 84, 1295-1302 (2005)

2. Grammelis, P., Skodras, G., Kakaras, E.: Effects of biomass cofiring with coal on ash properties. Part I: Characterisation and PSD. Fuel 85, 2310-2315 (2006)

3. Hartmann, D., Kaltschmitt, M.: Electricity generation from solid biomass via co-combustion with coal: energy and emission balances from a German case study. Biomass Bioenergy 16, 397-406 (1999)

4. Luts, D., Devoldere, K., Laethem, B., Bartholomeeusen, W., Ockier, P.: Co-incineration of dried sewage sludge in coal-fired power plants: a case study. Water Sci. Technol. 42, 259-268 (2000)

5. Hinds, W.C.: Aerosol Technology: Properties, Behaviour and Measurement of Airborne Particles, 2nd edn. Wiley, New York (1999)

6. Harrison, R.M., Grenfell, J.L., Savage, N., Allen, A., Clemitshaw, K.C., Penkett, S., Hewitt, C.N., Davison, B.: Observations of new particle production in the atmosphere of a moderately polluted site in eastern England. J. Geophys. Res. 105(17), 819-832 (2000)

7. Hughes, L.S., Allen, J.O., Bhave, P., Kleeman, M.J., Cass, G.R., Liu, D.-Y., Fergenson, D.P., Morrical, B.D., Prather, K.A.: Evolution of atmospheric particles along trajectories crossing the Los Angeles basin. Environ. Sci. Technol. 34, 3058-3068 (2000)

8. Yao, Q., Li, S.-Q., Xu, H.W., Zhuo, J.-K., Song, Q.: Studies on formation and control of combustion particulate matter in China: a review. Energy 34, 1296-1309 (2009)

9. Haynes, B.S., Neville, M., Quann, R.J., Sarofim, A.F.: Factors governing the surface enrichment of fly ash in volatile trace species. J. Colloid Interface Sci. 87, 266-278 (1982)

10. Seames, W.S.: An initial study of the fine fragmentation fly ash particle mode generated during pulverized coal combustion. Fuel Process. Technol. 81, 109-125 (2003)

11. Pueschel, R.F.: Aerosol formation during coal combustion: condensation of sulphates and chlorides on flyash. Geophys. Res. Lett. 3, 651-653 (1976)

12. Xu, M., Yu, D., Yao, H., Liu, X., Qiao, Y.: Coal combustiongenerated aerosols: formation and properties. Proc. Combust. Inst. 33, 1681-1697 (2011)

13. Miller, S.F., Miller, B.G.: The occurrence of inorganic elements in various biofuels and its effect on ash chemistry and behavior and use in combustion products. Fuel Proc. Technol. 88, 1155-1164 (2007)

14. Zeng, T., Sarofim, A.F., Senior, C.L.: Vaporisation of arsenic, selenium and antimony during coal combustion. Combust. Flame 126, 1714-1724 (2001)

15. Christensen, K.A., Stenholm, M., Livbjerg, H.: The formation of submicron aerosol particles, $\mathrm{HCl}$ and $\mathrm{SO}_{2}$ in straw-fired boilers. J. Aerosol Sci. 29, 421-444 (1998)

16. Fix, G., Seames, W., Mann, M., Benson, S., Miller, D.: The effect of combustion temperature on coal ash fine-fragmentation mode formation mechanisms. Fuel 113, 140-147 (2013) 
17. Quann, R.J., Neville, M., Sarofim, A.F.: A laboratory study of the effect of coal selection on the amount and composition of combustion-generated submicron particles. Combust. Sci. Technol. 74, 245-265 (1990)

18. Buhre, B.J.P., Hinkley, J.T., Gupta, R.P., Wall, T.F., Nelson, P.F.: Submicron ash formation from coal combustion. Fuel 84, 1206-1214 (2005)

19. Jokiniemi, J.K., Lazaridis, M., Lehtinen, K.E.J., Kauppinen, E.I.: Numerical simulation of vapour-aerosol dynamics in combustion processes. J. Aerosol Sci. 25, 429-446 (1994)

20. Johansen, J.M., Aho, M., Paakinen, K., Taipale, R., Egsgaard, H., Jakobsen, J.G., Frandsen, F.J., Glarborg, P.: Release of K, Cl and $\mathrm{S}$ during combustion and co-combustion with wood and highchlorine biomass in bench and pilot scale fuel beds. Proc. Combust. Inst. 34, 2363-2372 (2013)

21. Nussbaumer, T.: Combustion and co-combustion of biomass: fundamentals, technologies, and primary measures for emission reduction. Energy Fuels 17, 1510-1521 (2003)

22. Becidan, M., Todorovic, D., Skreiberg, O., Khalil, R.A., Backman, R., Goile, F., Skreiberg, A., Jovovic, A., Sorum, L.: Ash related behaviour in staged and non-staged combustion of biomass fuels and fuel mixtures. Biomass Bioenergy 41, 86-93 (2012)

23. Gao, X., Wu, H.: Combustion of volatiles produced in situ from fast pyrolysis of woody biomass: direct evidence on its substantial contribution to submicrometer particle (PM1) emission. Energy Fuels 25, 4172-4181 (2011)

24. Hupa, M.: Interaction of fuels in co-firing in FBC. Fuel 84, 1312-1319 (2005)

25. Brunner, T., Fluch, J., Obernberger, I., Warnecke, R.: Investigations of aerosol formation pathways during MSW combustion based on high-temperature impactor measurements. Fuel Proc. Technol. 105, 154-163 (2013)

26. Wiinikka, H., Gebart, R., Boman, C., Boström, D., Nordin, A., Öhman, M.: High temperature aerosol formation in wood pellets flames: spatially resolved measurements. Combust. Flame 147, 278-293 (2006)

27. Wiinikka, H., Gebart, R., Boman, C., Boström, D., Öhman, M.: Influence of fuel ash composition on high temperature aerosol formation in fixed bed combustion of woody biomass pellets. Fuel 86, 181-193 (2007)

28. Jiménez, S., Ballester, J.: Effect of co-firing on the properties of submicron aerosols from biomass combustion. Proc. Combust. Inst. 30, 2965-2972 (2005)

29. Jiménez, S., Pérez, M., Ballester, J.: Vaporisation of trace elements and their emission with submicrometer aerosols in biomass combustion. Energy Fuels 22, 2270-2277 (2008)

30. Glarborg, P., Marshall, P.: Mechanism and modelling of the formation of gaseous alkali sulphates. Combust. Flame 141, 22-39 (2005)

31. Hidiyarti, L., Frandsen, F., Livbjerg, H., Glarborg, P., Marshall, P.: An exploratory study of alkali sulphate aerosol formation during biomass combustion. Fuel 87, 1591-1600 (2008)

32. Jiménez, S., Ballester, J.: Formation of alkali sulphate aerosols in biomass combustion. Fuel 86, 486-493 (2007)

33. Jöller, M., Brunner, T., Obernberger, I.: Modeling of aerosol formation during biomass combustion in grate furnaces and comparison with measurements. Energy Fuels 19, 311-323 (2005)

34. Jöller, M., Brunner, T., Obernberger, I.: Modeling of aerosol formation during biomass combustion for various furnaces and boiler types. Fuel Proc. Technol. 88, 1136-1147 (2007)

35. Wiinikka, H., Gebart, R.: The influence of air distribution rate on particle emissions in fixed bed combustion of biomass. Combust. Sci. Technol. 177, 1747-1766 (2005)
36. Eckenfelder, W.W., Malina, J.F., Patterson, J.W.: Municipal sewage sludge management: a reference on processing, utilization and disposal, vol. 4, p. 526. Technomic Publishing Company, Lancaster (1998)

37. Lindström, E., Sandström, M., Boström, D., Öhman, M.: Slagging characteristics during combustion of cereal grains rich in phosphorus. Energy Fuels 21, 710-717 (2007)

38. Wang, Q., Zhang, L., Sato, A., Ninomiya, Y., Yamashita, T., Dong, Z.: Mineral interactions and their impact on the reduction of $\mathrm{PM}_{10}$ emissions during co-combustion of coal with sewage sludge. Proc. Combust. Inst. 32, 2701-2708 (2009)

39. Lopes, H., Gulyurtlu, I., Abelha, P., Crujeira, T., Salema, D., Freire, M., Pereira, R., Cabrita, I.: Particulate and PCDD/F emissions from coal co-firing with solid biofuels in a bubbling fluidised bed reactor. Fuel 88, 2373-2384 (2009)

40. Chao, C.Y.H., Kwong, P.C.W., Wang, J.H., Cheung, C.W., Kendall, G.: Co-firing coal with rice husk and bamboo and the impact on particulate matters and associated polycyclic aromatic hydrocarbon emissions. Biosource Technol. 99, 83-93 (2008)

41. Damoe, A.J., Wu, H., Frandsen, F.J., Glarborg, P., Sander, B.: Impact of coal fly ash addition on combustion aerosols $\left(\mathrm{PM}_{2.5}\right)$ from full-scale suspension-firing of pulverised wood. Energy Fuels 28, 3217-3223 (2014)

42. Strand, M., Pagels, J., Szpila, A., Gudmunsson, A., Swietlicki, E., Bohgard, M., Sanati, M.: Fly ash penetration through electrostatic precipitator and flue gas condenser in a $6 \mathrm{MW}$ biomass fired boiler. Energy Fuels 16, 1499-1506 (2002)

43. Lind, T., Hokkinen, J., Jokiniemi, J.K.: Electrostatic precipitator collection efficiency and trace element emissions from co-combustion of biomass and recovered fuel in fluidized-bed combustion. Environ. Sci. Technol. 37, 2842-2846 (2003)

44. Senior, C.L., Helble, J.J., Sarofim, A.F.: Emissions of mercury, trace elements, and fine particles from stationary combustion sources. Fuel Proc. Technol. 65, 263-288 (2000)

45. Lind, T., Kauppinen, E.I., Valmari, T., Klippel, N., Mauritzson, C.: Compositional penetration of pulverised coal combustion fly ash through the electrostatic precipitator. J. Aerosol Sci. 26, 13-14 (1995)

46. Sippula, O., Hokkinen, J., Puustinen, H., Yli-Pirila, P., Jokiniemi, J.: Particle emissions from small wood-fired district heating units. Energy Fuels 23, 2974-2982 (2009)

47. Whitby, K.T., Lundgren, D.A.: Mechanics of air cleaning. Trans. ASAE 8, 342-345 (1965)

48. Kan, H., London, S.J., Chen, G., Zhang, Y., Song, G., Zhao, N., Jiang, L., Chen, B.: Differentiating the effects of fine and coarse particles on daily mortality in Shanghai, China. Environ. Int. 33, 376-384 (2007)

49. D’Alessio, A., D’Anna, A., Gambi, G., Minutolo, P., Sgo, L.A., Violi, A.: Combustion generated nanoparticles. La Chimica e l'Industria 81, 1001-1006 (1999)

50. Valavenidis, A., Fiotakis, K., Vlachogianni, T.: Airborne particulate matter and human health: toxicological assessment and importance of size and composition of particles for oxidative damage and carcinogenic mechanisms. J. Environ. Sci. Health Part C 26(4), 339-362 (2008)

51. Saffari, A., Daher, N., Shafer, M.M., Schauer, J.J., Sioutas, C.: Global perspective on the oxidative potential of airborne particulate matter: a synthesis of research findings. Environ. Sci. Technol. 48, 7576-7583 (2014)

52. Salvi, S.: Health effects of ambient air on children. Paediatr. Respir. Rev. 8, 275-280 (2007)

53. Leskinen, J., Tissari, J., Uski, O., Virén, A., Torvela, T., Kaivosoja, T., Lamberg, H., Nuutinen, I., Kettunen, T., Joutsensaari, J., Jalava, P.I., Sippula, O., Hirvonen, M.-R., Jokiniemi, J.: Fine particle emissions in three different combustion conditions of a 
wood chip-fired appliance-particulate physico-chemical properties and induced cell death. Atmos. Environ. 86, 129-139 (2014)

54. Fernandez, A., Wendt, J.O.L., Cenni, R., Young, R.S., Witten, M.L.: Resuspension of coal and coal/municipal sewage sludge combustion generated fine particles for inhalation health effects studies. Sci. Total Environ. 287, 265-274 (2002)

55. Fernandez, A., Wendt, J.O.L., Witten, M.L.: Health effects engineering of coal and biomass combustion particulates: influence of zinc, sulfur and process changes on potential lung injury from inhaled ash. Fuel 84, 320-1327 (2005)

56. Villeneuve, J., Palacios, J.H., Savoie, P., Godbout, S.: A critical review of emission standards and regulations regarding biomass combustion in small scale units $(<3 \mathrm{MW})$. Biosource Technol. 111, 1-11 (2012) 